\title{
Reappraisal of the black mildews (Meliolales) on Hevea brasiliensis
}

\author{
Danilo B. Pinho, Jaime Honorato Junior, André L. Firmino, Braz T. Hora Junior, Eduardo S. G. Mizubuti \\ \& Olinto L. Pereira
}

Departamento de Fitopatologia, Universidade Federal de Viçosa, 36570-900, Viçosa, MG, Brazil

Author for correspondence: Olinto L. Pereira, e-mail: oliparini@ufv.br

\begin{abstract}
The rubber tree (Hevea brasiliensis) is host to several fungal species, including Irenopsis heveae as described by Hansford in 1961, which causes black mildew on leaves. One specimen of Irenopsis heveae from the state of Espírito Santo and two from the state of Pará were analyzed and showed some morphological differences. Some structures are similar to morphological characteristics as described and illustrated by Vincens in 1915 for Meliola heveae. Morphological comparisons with the type specimen of $I$. heveae and the alignment of the nucleotide sequences of the $28 \mathrm{~S}$ rDNA region, however, indicate that the three samples belong to the same species. According to these data $M$. heveae and $I$. heveae are heterotypic synonyms with $M$. heveae being the older name. As the name $I$. heveae is already occupied by Hansford, Irenopsis vincensii is proposed as new name for the black mildew on H. brasiliensis. This is the first contribution of molecular sequence data for this species.
\end{abstract}

Key words: Forest pathology, Meliolaceae, rubber tree, Sordariomycetes, tropical fungi.

\section{INTRODUCTION}

The rubber tree [Hevea brasiliensis (Willd. ex A. Juss.) Müll. Arg. - Euphorbiaceae] is the sole significant source of natural rubber in the world. This species is the host of numerous plant pathogenic fungi, including Microcyclus ulei (Henn.) Arx, the agent of South American Leaf Blight, the most destructive disease of the rubber tree in humid tropical areas (Gasparotto et al., 1997). Nevertheless, as new areas are being explored for the cultivation of rubber trees, any information on the mycobiota of $H$. brasiliensis is of scientific interest.

There are two species of black mildews that have been described on rubber trees: Irenopsis heveae Hansf. and Meliola heveae Vincens (Hansford, 1961). Species of Meliola are recognized by the presence of mycelial setae on hyphae or around perithecia while Irenopsis spp. develop perithecial setae (Hansford, 1961). The aim of this study was to compare the morphological differences of specimens collected in different regions of Brazil and to provide molecular sequence data for this species.

\section{MATERIALS AND METHODS}

\section{Sample collection and morphology}

During a survey of black mildews in Brazil (Pinho et al., 2012a; 2012b; 2013), rubber trees were found to be colonized by black mildews in a commercial nursery located in Altamira, Pará, in native rubber trees in the Amazon rainforest (center of origin of $H$. brasiliensis) in the state
Pará, and in a commercial plantation from clone FX 3864 in Sooretama, Espírito Santo, Brazil.

Samples of infected leaves were collected, photographed, dried in a plant press, and later examined in the laboratory. Representative samples were deposited in the herbarium of the Universidade Federal de Viçosa (Herbarium VIC). Freshly collected samples were examined under a Olympus SZX7 stereomicroscope. Fungal structures were scraped with a scalpel from the plant surface and mounted in lactophenol. To observe mycelial branching, a drop of nail polish was placed on selected areas of the colonies, and after it had dried completely, it was removed from the leaf together with the entire intact external mycelium, and the film was mounted directly in lactophenol (Hosagoudar \& Kapoor, 1985). Biometric data were based on 30 measurements of structures, and illustrations were prepared with a Carl Zeiss Standard W fitted with a drawing tube. For scanning electron microscopy, air-dried material was directly mounted and coated with a thin layer of gold in a sputter coater (Balzers model FDU 010) for 2 min. Photographs were made with a Carl-Zeiss Model LEO VP 1430 scanning electron microscope (SEM).

DNA extraction, PCR conditions and phylogenetic analysis

To obtain representative fungal DNA, ca. 50 fertile perithecia of Irenopsis sp. were examined under a stereomicroscope to check for possible contamination by other fungi. Clean perithecia were removed from the colonies with a fine needle and placed into a microcentrifuge tube ( 1.5 
$\mathrm{mL}$ ). Genomic DNA extraction was performed using the Wizard Genomic DNA Purification Kit (Promega) following Pinho et al. (2012a). Target regions of the partial 28S rDNA and Internal Transcribed Spacer (ITS) were amplified using the primers LR0R (5'-ACCCGCTGAACTTAAGC-3') and LR5 (5'-TCCTGAGGGAAACTTCG-3') for partial 28S rDNA (Vilgalys \& Hester, 1990) and ITS1 (5'-TCC GTAGGTGAACCTGCGG-3') and ITS4 (5'TCCTCCGCTTATTGATATGC-3') for ITS (White et al., 1990). PCR reactions included the following ingredients for each $25 \mu \mathrm{L}$ reaction: $12.5 \mu \mathrm{L}$ of Dream Taq TM PCR master mix 2x (MBI Fermentas), $1 \mu \mathrm{L}$ of $10 \mu \mathrm{m}$ of each forward and reverse primer (synthesized by Invitrogen), $1 \mu \mathrm{L}$ of dimethyl sulfoxide (DMSO, Sigma-Aldrich), $5 \mu \mathrm{L}$ of $100 \times$ $(10 \mathrm{mg} / \mathrm{mL})$ bovine serum albumin (BSA, Sigma-Aldrich), $2 \mu \mathrm{L}$ of genomic DNA, and $2.5 \mu \mathrm{L}$ of nuclease-free water.

The thermal cycle consisted of 1 cycle at $95^{\circ} \mathrm{C}$ for 5 min, followed by 35 cycles of $94^{\circ} \mathrm{C}$ for $1 \mathrm{~min}$ (denaturation), $53^{\circ} \mathrm{C}$ for $1 \mathrm{~min}$ (annealing), $72^{\circ} \mathrm{C}$ for $2 \mathrm{~min}$ (elongation), and $72^{\circ} \mathrm{C}$ for $10 \mathrm{~min}$ (final extension). The PCR products were analyzed by $2 \%$ agarose electrophoresis gels stained with Gel Red (Biotium Inc.) in a $1 \times$ TAE buffer and visualized under UV light to check for amplification size and purity. The PCR products were purified and sequenced commercially (Macrogen Inc.). DNA isolations from all specimens were repeated in order to verify that the DNA isolated, amplified, and sequenced was of black mildew origin. The nucleotide sequences were edited with DNA Dragon software (Hepperle, 2011). All sequences were checked manually, and nucleotides with ambiguous positions were clarified using both primer direction sequences. New sequences were deposited in GenBank (http://www.ncbi.nlm.nih.gov) and sequences of $28 \mathrm{~S}$ rDNA of additional species were retrieved for comparison (Table 1). The resulting alignment was deposited into TreeBASE (http://www.treebase.org/) with the accession number S14203. Phylogenetic analysis was conducted as described by Pinho et al. (2012a).

\section{RESULTS}

\section{Taxonomy}

The morphological description of the specimens found on $H$. brasiliensis is given below.
Irenopsis vincensii Pinho \& O.L. Pereira, nom. nov. Figures 1 and 2

$\equiv$ Meliola heveae Vincens, Bull. Soc. Path. Veg. France 2: 26, 1915. On Hevea brasiliensis, Brazil, Pará, Belém, collected between 1910 and 1915. The type was not designated by Vincens and the specimen was not located in Paris (Muséum National d'Histoire Naturelle-P) and Goeldi (Museu Paraense Emílio Goeldi-MG) herbaria. Currently, there is only a drawing in Vincens (1915) according to Hansford (1961).

= Irenopsis heveae Hansf., Beihefte zur Sydowia 2: 207, 1961. On Hevea brasiliensis, Peru, Rio Chipurana, Oromina nursery, Jul 1942, R. Russell (Herbarium BPI 698253-Holotype).

MycoBank: MB804802

Etymology: Named after P.F. Vincens, who was the first to describe this fungus.

Colonies amphigenous, scattered or coalescent, black, 1-6 mm diameter. External mycelium dark brown. Hyphae dark brown, septate, slightly straight to undulate, branching in acute angles, bearing appressoria and phialides. Hyphal cells 22.5-37.5 × 3.5-6 $\mu \mathrm{m}$. Appressoria alternate, antrorse, straight to slightly curved; stalk cells dark brown, cylindrical to cuneate, 7.5-10 × 7.5-10 $\mu \mathrm{m}$; head cells dark brown, often irregularly rounded-angulose, sometimes entire, globose, oblong to pyriform, straight to slightly curved, $12.5-20 \times 10-15 \mu \mathrm{m}$. Phialides brown, mixed with appressoria, opposite to alternate, ampulliform, 17.5-22.5 × 5-7.5 $\mu \mathrm{m}$. Perithecia black, loosely aggregated or scattered, globose, verrucose, $150-270 \mu \mathrm{m}$ in diameter. Perithecial setae 2-9 per ascoma, light brown to dark brown, upright, straight to curved in the lower half, spirally twisted to uncinate in the upper half, obtuse, slightly bent to tightly contorted at the apex, more or less verrucose, 50-70 $\times 5-7.5$ $\mu \mathrm{m}$. Asci evanescent. Ascospores hyaline when inside the ascus, becoming brown to dark brown with age, cylindrical to slightly ellipsoid, rounded at the tips, sometimes with small conoid-obtuse end cells, 4-septate, constricted at the septae, sometimes with an enlarged middle cell, 37.5-47.5 $\times 15-22.5 \mu \mathrm{m}$.

Further specimens examined: on living leaves of Hevea brasiliensis. BRAZIL: Pará: Altamira, in a commercial nursery, 23 May 2011, B. T. Hora Junior (VIC

TABLE 1 - GenBank accession numbers of 28S rDNA sequences used in the phylogenetic analysis.

\begin{tabular}{llcl}
\hline \hline Species & Specimen & GenBank access no. & Reference \\
\hline Appendiculella lozanellae & MP3432 & DQ508302 & Rodríguez \& Piepenbring, 2007 \\
Asteridiella obesa & VIC31239 & JX096809 & Pinho et al., 2012a \\
Endomeliola dingleyae & PDD98304 & GU138866 & unpublished \\
Irenopsis vincensii & VIC31750 & JX133162 & this study \\
I. vincensii & VIC31751 & JX133163 & this study \\
I. vincensii & VIC31752 & JX096807 & Pinho et al., 2012a \\
Meliola centellae & VIC31244 & JQ734545 & Pinho et al., 2012a \\
M. vernaliae & VIC31240 & JX096808 & Pinho et al., 2012a \\
\hline
\end{tabular}




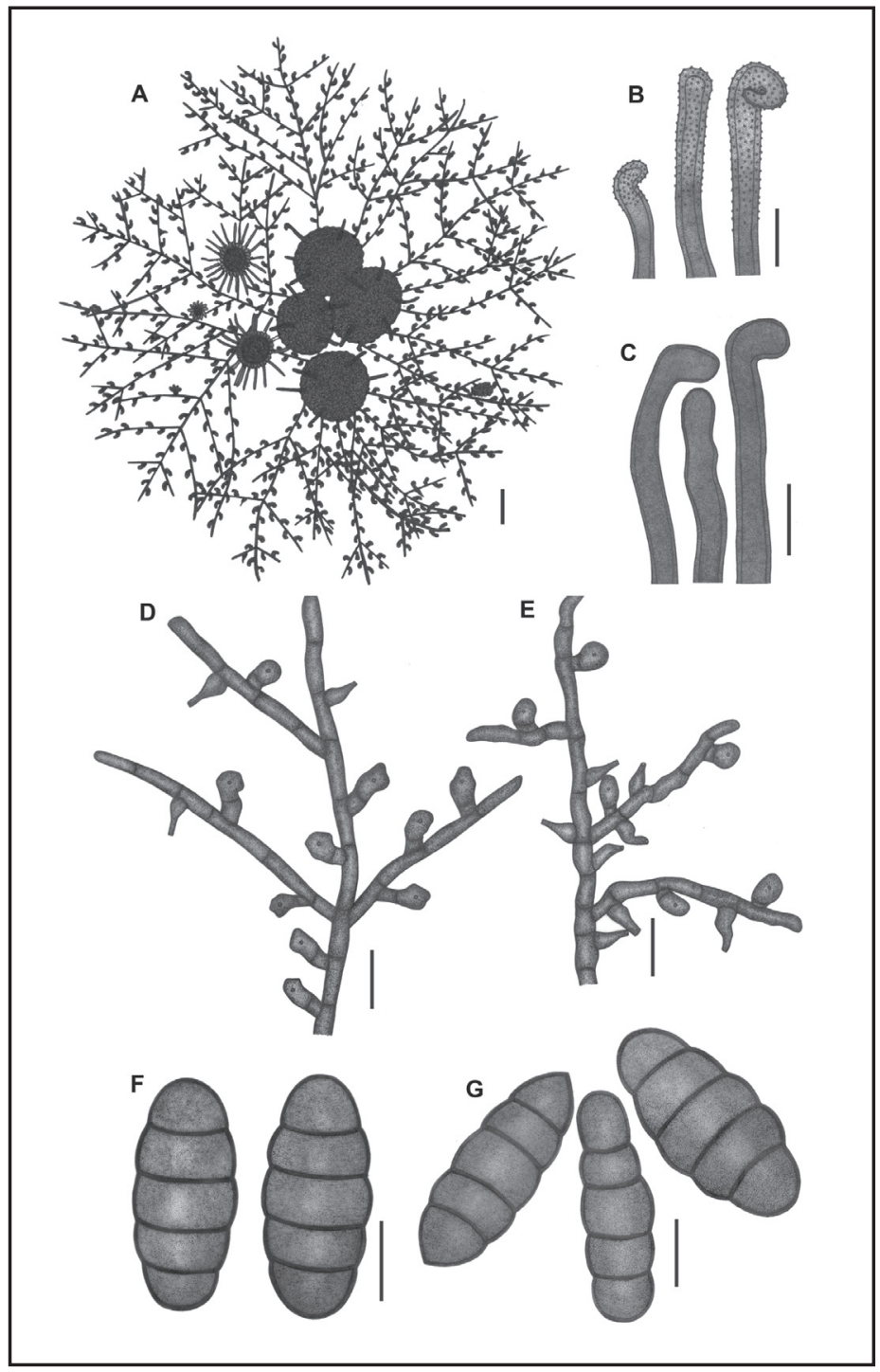

FIGURE 1 - Irenopsis vincensii on Hevea brasiliensis. A. Colony (VIC 31752). Note the setose perithecia and the absence of mycelial setae. B. Perithecial setae (VIC 31751). C. Perithecial setae (VIC 31752). D. External mycelium with appressoria and phialides (VIC 31752). E. External mycelium with appressoria and phialides (VIC 31750). F. Ascospores (VIC 31751). G. Ascospores (VIC 31752). Bars: $A=100 \mu \mathrm{m} ; \mathrm{B}-\mathrm{G}=15 \mu \mathrm{m}$.

31750); on living leaves of $H$. brasiliensis. BRAZIL: Pará: Belterra, on native rubber trees in the Amazon Rainforest, 5 May 2011, O. L. Pereira (VIC 31751); on living leaves of $H$. brasiliensis. BRAZIL: Espírito Santo: Sooretama, in a commercial plantation, 13 Apr 2010, D. B. Pinho (VIC 31752-Epitype).

Known distribution: Known to cause black mildew on Hevea brasiliensis in Peru (Hansford, 1961) and Brazil (Vincens, 1915).

\section{Molecular analysis}

The DNA extraction of the type material of $I$. heveae was not allowed. While $28 \mathrm{~S}$ rDNA sequence data were successfully obtained for samples recently collected from the nursery and Amazonic rainforest, three other attempts for amplification of the ITS region were unsuccessful. The partial 28S rDNA sequences show $100 \%$ base pair identity, cluster together in the phylogenetic tree (Figure 3), and support the conspecificity of three specimens recently collected in Brazil.

\section{DISCUSSION}

Thirteen species of black mildew are known to colonize members of the Euphorbiaceae in Brazil (Hansford 1961; Pinho et al., 2012b), but only Meliola heveae has been recorded on Hevea brasiliensis in Brazil up to now (Vincens, 1915). The fungi found on H. brasiliensis in the context of the present study have perithecial setae, so they are typical species of Irenopsis. Morphological variation between the three specimens was observed by light and scanning electron microscopy (Table 2). The morphology of appressoria, perithecia, setae, and ascospores of specimens from different locations, was similar to the morphology of the respective structures as described for $I$. heveae or $M$. heveae by Hansford (1961) or Vincens (1915), respectively. 

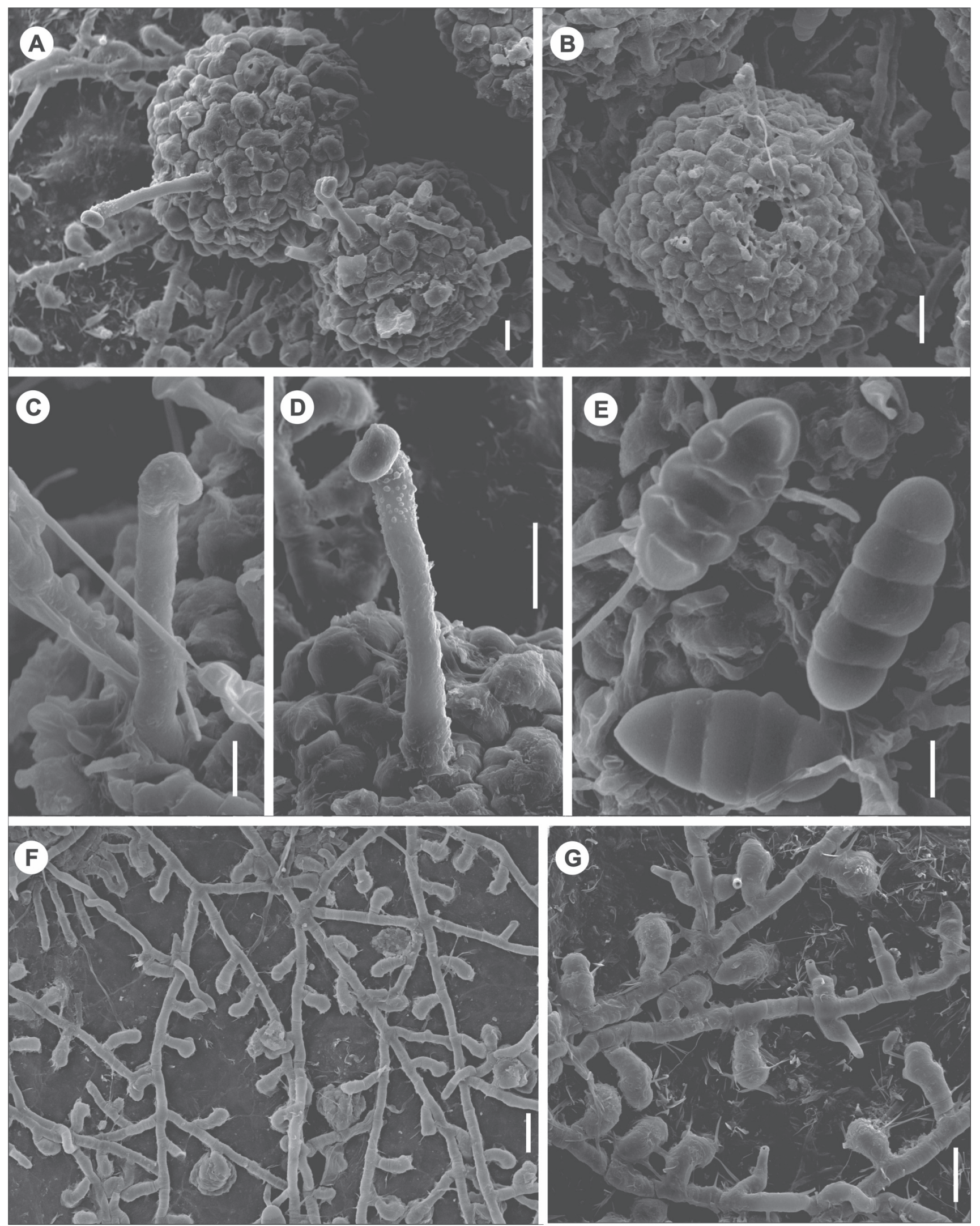

FIGURE 2 - SEM photographs from Irenopsis vincensii on Hevea brasiliensis. A. Perithecia (VIC31750). B. Perithecium with evident ostiolum (VIC31750). C. Smooth seta (VIC31752). D. Verrucose perithecial seta (VIC31751). E. Ascospores (VIC31752). F. Superficial hyphae bearing appressoria (VIC31750). G. Superficial hyphae bearing aprressoria and phialides (VIC31752). Bars: A, D, G = 20 $\mu$ m; B, $\mathrm{F}=30 \mu \mathrm{m} ; \mathrm{C}, \mathrm{E}=10 \mu \mathrm{m}$. 


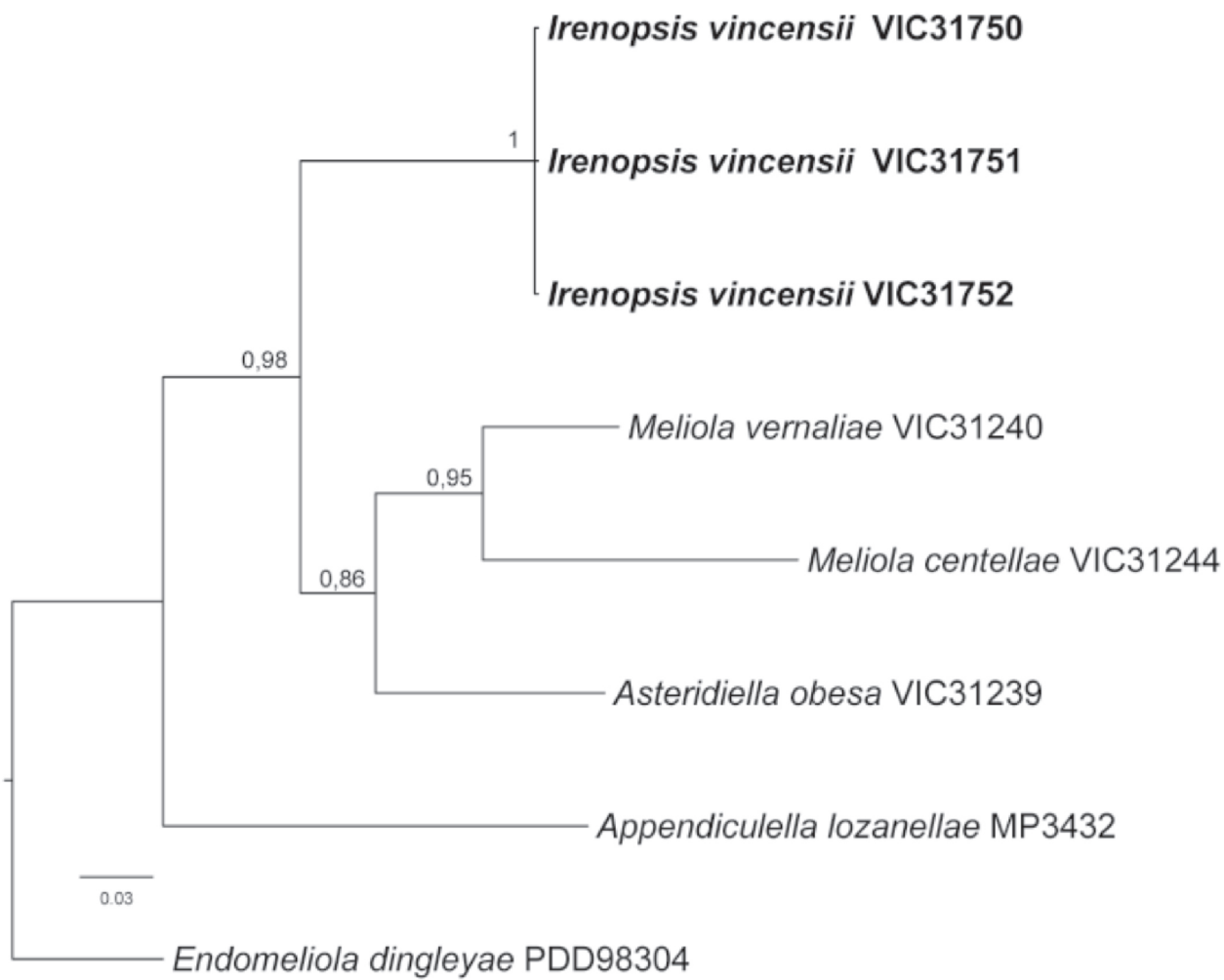

FIGURE 3 - Phylogenetic tree inferred from Bayesian inference of $28 \mathrm{~S}$ rDNA sequences of specimens of the Meliolales. Bayesian posterior probabilities are indicated above the nodes. Specimen numbers are indicated after species names, and the specimens used in this study are highlighted in bold. The tree is rooted with Endomeliola dingleyae S. Hughes \& Piroz.

TABLE 2 - Morphological characteristics according to the original descriptions of Irenopsis heveae and Meliola heveae and according to observations of specimens of I. vincensii collected in a nursery (VIC31750), Amazon rainforest (VIC31751), or a plantation (VIC31752).

\begin{tabular}{|c|c|c|c|c|c|}
\hline $\begin{array}{l}\text { Morphological } \\
\text { characteristic }\end{array}$ & Irenopsis heveae & Meliola heveae & Nursery & Amazon rainforest & Plantation \\
\hline Ascospores & Cylindrical & $\begin{array}{l}\text { Ellipsoid with } \\
\text { enlarged middle } \\
\text { cells }\end{array}$ & Cylindrical & Cylindrical & $\begin{array}{l}\text { Ellipsoid with } \\
\text { enlarged middle } \\
\text { cells }\end{array}$ \\
\hline Perithecia & Scattered & Aggregated & $\begin{array}{l}\text { Scattered or } \\
\text { aggregated }\end{array}$ & Scattered & Aggregated \\
\hline Perithecial setae & $\begin{array}{l}\text { Light brown, tightly } \\
\text { verrucose, straight in } \\
\text { lower half and curved, } \\
\text { spirally twisted or } \\
\text { uncinate in the upper } \\
\text { half with a tightly } \\
\text { contorted apex }\end{array}$ & $\begin{array}{l}\text { Dark brown, } \\
\text { smooth or slightly } \\
\text { verrucose, upright } \\
\text { with an obtuse or } \\
\text { slightly bent apex }\end{array}$ & $\begin{array}{l}\text { Light brown, tightly } \\
\text { verrucose, straight } \\
\text { in lower half and } \\
\text { curved, spirally } \\
\text { twisted or uncinate } \\
\text { in the upper half } \\
\text { with a tightly } \\
\text { contorted apex }\end{array}$ & $\begin{array}{l}\text { Light brown, tightly } \\
\text { verrucose, straight } \\
\text { in lower half and } \\
\text { curved, spirally } \\
\text { twisted or uncinate } \\
\text { in the upper half } \\
\text { with a tightly } \\
\text { contorted apex }\end{array}$ & $\begin{array}{l}\text { Dark brown, } \\
\text { smooth or slightly } \\
\text { verrucose, upright } \\
\text { with an obtuse or } \\
\text { slightly bent apex }\end{array}$ \\
\hline Appressoria & $\begin{array}{l}\text { Irregularly rounded to } \\
\text { angular }\end{array}$ & $\begin{array}{l}\text { Globose and oblong } \\
\text { to pyriform }\end{array}$ & $\begin{array}{l}\text { Globose and oblong } \\
\text { to pyriform }\end{array}$ & $\begin{array}{l}\text { Irregularly rounded } \\
\text { to angular }\end{array}$ & $\begin{array}{l}\text { Irregularly rounded } \\
\text { to angular }\end{array}$ \\
\hline
\end{tabular}

Ascospores, perithecia and perithecial setae of the specimens collected in the nursery (VIC 31750) and Amazon Rainforest (VIC 31751) (Figure 1 and 2) are similar to the respective structures of $I$. heveae as described by Hansford (1961). The characteristics of appressoria of the specimens collected from the Amazon Rainforest and commercial plantation (VIC 31752) matched with the description of I. heveae by Hansford (1961). The ascospores, perithecia, and perithecial setae of the specimens collected in the commercial plantation and appressoria of the specimen collected from the nursery, however, are similar to those described for $M$. heveae by Vincens (1915).

Meliola heveae was originally reported and described from Brazil by Vincens (1915). The type was not designated and the specimen could not be located in herbaria in Paris (Muséum National d'Histoire Naturelle-P) or Goeldi 
(Museu Paraense Emílio Goeldi-MG). Vincens (1915) described perithecia bearing setae and according to a remark by Hansford, this species may belong to Irenopsis, a genus proposed after the description of $M$. heveae (Hansford, 1961). Hansford studied a black mildew on $H$. brasiliensis from Peru and based on the presence of perithecial setae, he described this species as I. heveae, without previous analysis of the specimen described by Vincens (Hansford, 1961). Apart from the position of the setae, Irenopsis heveae presents minor morphological differences when compared to the published description of $M$. heveae. We examined the morphology of the type material of $I$. heveae and confirmed the description of Hansford (1961). The type material of $M$. heveae could not be located and is probably lost, thus the identity of this species remains doubtful. The presence of perithecial setae in the specimens collected in Brazil, close to the type locality of $M$. heveae, and morphological characteristics similar to $M$. heveae indicate that only one species occurs on $H$. brasiliensis. Morphological variation between specimens can occur, because according to Hansford (1961) species in the Meliolales vary considerably even between different colonies growing on the same leaf and between collections on the same host from different regions. Based on morphological comparisons of the three recent samples from Brazil and the type specimen of $I$. heveae, the published description of $M$. heveae, and molecular data, we conclude that $M$. heveae and I. heveae are heterotypic synonyms. M. heveae is the older name, but the name of the possible new combination, I. heveae, is already occupied by Hansford. Thus, Irenopsis vincensii is proposed as a new name for Meliola heveae Vincens and Irenopsis heveae Hansford.

\section{ACKNOWLEDGEMENTS}

The authors are thankful to the center for biodiversity studies of the Michelin Ecological Reserve for logistical and financial support and the Instituto Chico Mendes (ICNBio) which gave permission to the corresponding author to collect in protected areas in Pará. The authors wish to thank the Conselho Nacional de Desenvolvimento Científico e Tecnológico - CNPq for fellowships. The authors would like to acknowledge the Nucleus of Microscopy and Microanalysis at the Universidade Federal de Viçosa (http://www.nmm.ufv. $\mathrm{br} /$ ) for providing the equipment and use of its facilities (including funding from $\mathrm{CNPq}$, Fundação de Amparo à Pesquisa do Estado de Minas Gerais - FAPEMIG and Financiadora de Estudos e Projetos - FINEP) and Karla V.
G. Ribeiro for technical assistance. We are very grateful to Shannon Dominik from the US National Fungus Collections (Herbarium BPI)/USDA, for her valuable help allowing us to examine the herbarium BPI 698253Holotype. We are grateful to Maria Catarina M. Kasuya (DMB/UFV), Dartanhã J. Soares (EMBRAPA Algodão), Harold C. Evans (CABI), Robert W. Barreto (DFP/UFV), Meike Piepenbring (Goethe Universität Frankfurt) and the anonymous reviewers for their critical remarks and improvement of the text.

\section{REFERENCES}

Gasparotto L, Santos AF, Pereira JCR, Ferreira FA (1997) Doenças da seringueira no Brasil. Brasília DF. EMBRAPA.

Hansford CG (1961) The Meliolineae - A monograph. Beihefte zur Sydowia 2:1-806.

Hepperle D (2011) DNA Dragon 1.4.1 - DNA Sequence Contig Assembler Software. Available at: http:/www.dna-dragon.com/ Accessed on November 15, 2011.

Hosagoudar VB, Kapoor JN (1985) New technique of mounting Meliolaceous fungi. Indian Phytopathology 38:548-549.

Pinho DB, Firmino AL, Pereira OL, Ferreira Junior WG (2012a) An efficient protocol for DNA extraction from Meliolales and the description of Meliola centellae sp. nov. Mycotaxon 122:333345 .

Pinho DB, Pereira OL, Firmino AL, Silva M, Ferreira-Junior WG, Barreto RW (2012b) New Meliolaceae from the Brazilian Atlantic Forest 1. Species on hosts in the families Asteraceae, Burseraceae, Euphorbiaceae, Fabaceae and Sapindaceae. Mycologia 104:121137.

Pinho DB, Pereira OL, Firmino AL, Ferreira-Junior WG (2013) New Meliolaceae from the Brazilian Atlantic Forest 2. Species on host families Annonaceae, Cecropiaceae, Meliaceae, Piperaceae, Rubiaceae, Rutaceae and Tiliaceae. Mycologia 105:697-711.

Rodríguez D, Piepenbring M (2007) Two new species of Appendiculella (Meliolaceae) from Panama. Mycologia 99:544552.

Vilgalys R, Hester M (1990) Rapid genetic identification and mapping of enzymatically amplifed ribosomal DNA from several Cryptococcus species. Journal of Bacteriology 172:4239-4246.

Vincens PF (1915) Contribution à l'étude des maladies de l'Hevea brasiliensis dans la vallée de l'Amazone. Bulletin de la Société de Pathologie Végétale de France 2:11-27.

White TJ, Bruns T, Lee S, Taylor J (1990) Amplifcation and direct sequencing of fungal ribosomal RNA genes for phylogenetics. In: Innis MA, Gelfand DH, Sninsky JJ, White TJ (Eds.) PCR Protocols: A Guide to Methods and Applications. San Diego CA, USA. Academic Press. pp. 315-322. 